УДК 330.3

(C) 2013

Брижань І. А., кандидат економічних наук

Полтавський національний технічний університет імені Юрія Кондратюка

\title{
УМОВИ ТА ЧИННИКИ ПЕРЕХОДУ УКРАЇНИ ДО МОДЕЛІ СТАЛОГО РОЗВИТКУ
}

\section{Рецензент - доктор економічних наук, професор Б. Я. Кузняк}

\begin{abstract}
Висвітлено необхідність переходу Украӥни до моделі сталого розвитку. Підкреслено, щзо нині Україна може вирішити сучасні проблеми забезпечення економічного зростання в умовах обмеженості та виснаження природних ресурсів, загрози виникнення техногенної катастрофи лише використовуючи принципи збалансованого розвитку, за якого гармонізуються економічні, соиіальні й екологічні складові зростання. Проаналізовано основні передумови та запропоновано комплекс інструментів $i$ заходів, спрямованих на прискорення втілення Україною концепиії збалансованого розвитку.
\end{abstract}

Ключові слова: сталий розвиток, збалансований розвиток, еколого-орієнтований розвиток, екологічні інновації.

Постановка проблеми. Реструктуризаційні зрушення в економіці України та ії орієнтація на пріоритети світового розвитку вимагають розробки й формування нових підходів у сфері управління економічним розвитком. Забезпечення високих темпів економічного зростання України - умова іiі успішної інтеграції в Європейське співтовариство. Проте на сьогодні, не зважаючи на незначне покращання економічної ситуації в Україні, рівень іiі конкурентоспроможності залишається досить низьким. До того ж спостерігається подальше погіршення екологічних показників.

Україна належить до однієї з найбільш забруднених та екологічно проблемних пострадянських країн: рівень навантаження на природне середовище в 4-5 разів перевищує аналогічні показники в інших країнах. За ступенем забруднення й деградації довкілля Україна посідає одне з перших місць у пострадянському суспільстві: при питомій вазі території в 2,7 \% викиди шкідливих речовин до атмосфери досягають $18 \%$, скидання стічних вод у поверхневі водойми - $12 \%$, щорічне складування відходів - 19 \% від (у недалекому минулому) загальносоюзних показників [2]. Аналіз абсолютних та інтегрованих показників техногенного навантаження на навколишнє середовище України свідчить про те, що екологічна ситуація в країні - досить складна; цілком реальною залишається загроза виникнення еко- логічної катастрофи.

Багатоаспектність i масштабність проблеми пояснюють актуальність вибору та обгрунтування напрямів подальшого економічного розвитку України з урахуванням необхідності зниження антропогенного навантаження на навколишнє середовище. Погіршення екологічної ситуації в Україні, а відтак, і стану здоров'я населення (починаючи з 1991 року в Україні смертність перевищує народжуваність; за останні 10 років кількість населення зменшилася на 3,7 млн осіб) вимагають якнайшвидшого переходу країни до так званої сталої економіки, що веде до підвищення якості життя людини, не руйнуючи його природних основ.

Аналіз останніх досліджень і публікацій, у яких започатковано розв'язання проблеми. Дослідженням економічної природи та причин економічного розвитку, зростання багатства i його нагромадження, а також формування системи ефективного розподілу й перерозподілу капіталу присвячено чимало робіт вчених. 3-поміж сучасних зарубіжних дослідників макроекономічного розвитку передусім необхідно відзначити Р. Нельсона, С. Уінтера [9]. Складові та передумови економічного зростання в країнах-лідерах світового економічного розвитку були розглянуті російськими авторами, серед яких М. Сршов, В. Гутник, А. Наумов [5]. Проблеми сталого розвитку досліджували у своїх працях відомі зарубіжні вчені, серед яких Деніс і Донелла Медоуз та Й. Рандерсон, Г. Дейлі [8]. Дану проблему всебічно досліджують i такі українські вчені: О. Г. Білорус М. А. Голубець, М. І. Долішній, В. С. Кравців, Л. Г. Мельник, В. П. Мікловда, В. П. Прадун, В. М. Трегобчук, O. I. Фурдичко, М. І. Хилько та ін. Фундаментальні положення теорії економічного зростання та сталого розвитку економіки розглянуті в роботі Б. Карпінського, С. Божко, О. Карпинської [6]. Вченими опрацьовано теоретичні аспекти сталого розвитку, проаналізовано актуальні проблеми реалізації сталого розвитку України, розглянуто регіональні та галузеві особливості. Водночас реалізація концепції сталого розвитку потребує 
більш глибокого аналізу як проблем, так i шляхів їх вирішення.

Метою даного дослідження $\epsilon$ визначення основних передумов та інструментів, що сприяють активізації переходу України на модель сталого розвитку.

Результати дослідження. На сучасному етапі історичну перспективу людства насамперед визначає екологічний фактор. Стає очевидним вплив екологічних умов на розвиток усіх без винятку компонентів соціуму. За сучасних темпів зростання населення планети і загальних обсягів виробництва навіть для підтримки антропогенного впливу на біосферу незмінним, не допускаючи його зростання, потрібно протягом найближчих десятиліть знизити в кілька разів середнє глобальне навантаження на навколишнє середовище, що припадає на одиницю ВНП. Ще на початку 1970-х рр. Д. Форрестером, Д. Медоузом та ін. було зроблено припущення, що при збереженні існуючих тенденцій зростання світового населення, розвитку промислового виробництва i, як наслідок, - експоненційного збільшення забруднення навколишнього середовища й виснаження природного потенціалу планети настане так звана «глобальна катастрофа» $[13,14]$. Тому перед економікою всіх країн світу стоїть дійсно глобальна проблема, що вимагає невідкладного вирішення.
Дана проблема $є$ актуальною й для України. Незважаючи на те, що чисельність населення країни постійно знижується, обсяги шкідливих викидів у повітряне середовище зростають. Особливо небезпечним є збільшення викидів двоокису вуглецю: починаючи 32009 року темпи зростання викидів двоокису вуглецю перевищують індекси фізичного обсягу валового внутрішнього продукту [3,4]. До того ж викликає занепокоєння стан водних ресурсів країни - за останні 10 років питомі скиди забруднених стоків на одиницю ВВП збільшилась у 3,67 разу, а частка об'єму забруднених вод у загальному об'ємі стічних вод, скинутих у водні об'єкти, в 2,35 разу [10]. Тому зниження навантаження на навколишнє середовище, що припадає на одиницю валового внутрішнього продукту, $\epsilon$ вкрай важливим для України.

Населення і виробництво в нашій країні сконцентровані в районах, де стан навколишнього середовища вже давно не відповідає екологічним вимогам і $\epsilon$ небезпечним для здоров'я й навіть життя людей. В Донбасі та Придніпров'і концентрація шкідливих речовин в атмосфері перевищує гранично допустимі норми у 5-10, а 3 окремих інгредієнтів - навіть у 15-20 разів [7]. $\mathrm{У}$ цих регіонах і надалі буде розвиватися виробництво, а отже, небезпечна екологічна ситуація буде тільки поглиблюватися.

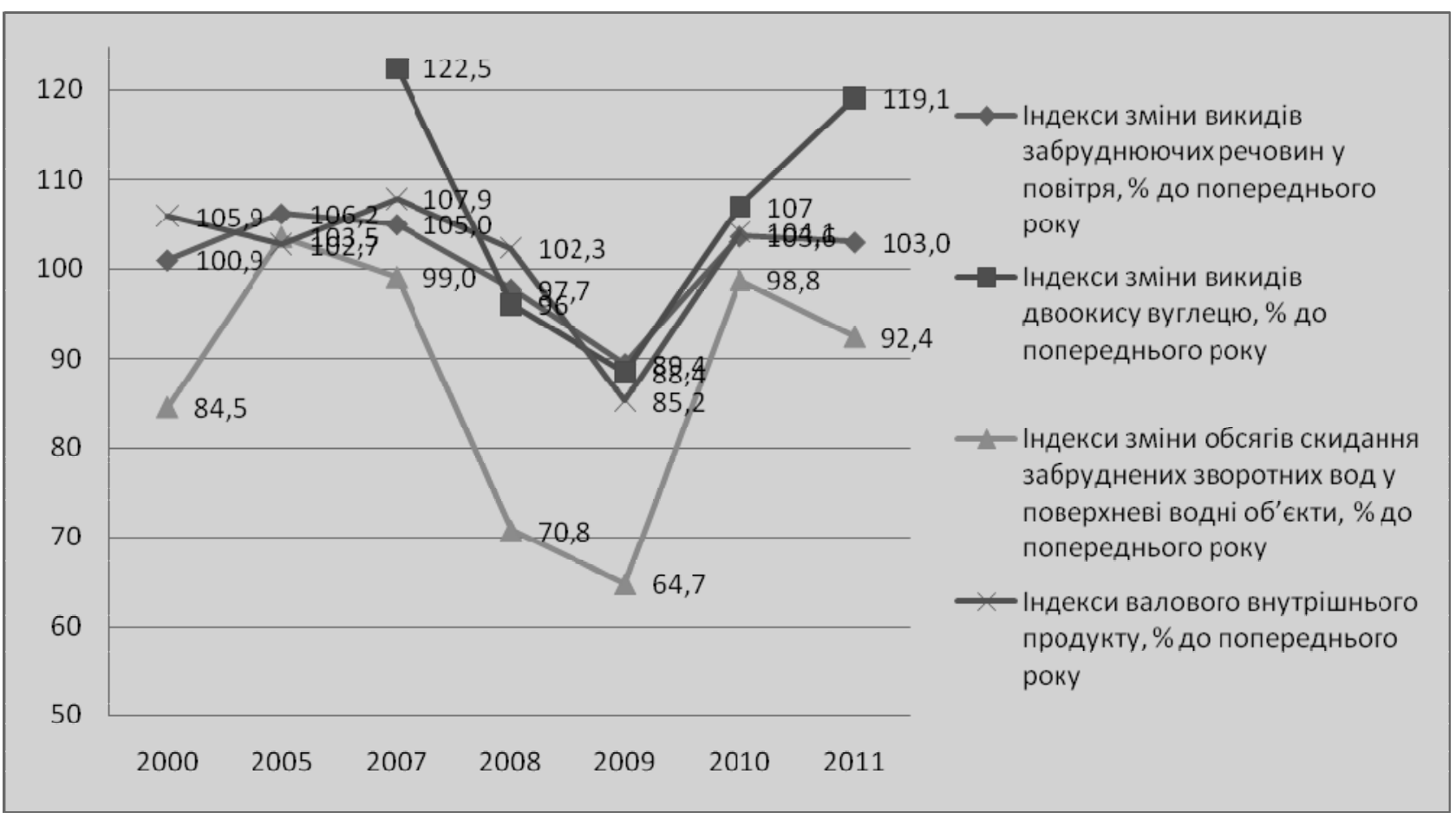

Рис. Динаміка валового внутрішнього продукту та шкідливих викидів у водне і повітряне середовища Украӥни 
Високий рівень забруднення всіх природних ресурсів і зменшення якості екологічних послуг відображає поглиблення кризи у взаємодії суспільства й навколишнього середовища. Стан довкілля та екологічної інфраструктури впливає на якість і темпи економічного зростання. В Україні назріла необхідність вирішення нових економічних задач, що вимагає пошуку вдосконалених підходів, здатних пояснити й забезпечити безперервне економічне зростання в нових умовах функціонування. Серед теорій, які в тій чи іншій мірі спрямовані на вирішення сучасних проблем забезпечення економічного зростання в умовах обмеженості та виснаження природних ресурсів, загрози виникнення техногенної катастрофи, слід виділити теорію сталого розвитку, яка пропонується на зміну концепції економічного розвитку «кінця труби». Згідно $з$ нею, за мету ставиться такий розвиток суспільства, за якого здійснюється задоволення потреб нинішніх поколінь, що не ставить під загрозу їхньої можливості задовольняти свої потреби.

Теорія сталого розвитку $є$ альтернативою парадигмі економічного зростання, що ігнорує екологічну небезпеку. Її формування здійснювалося внаслідок поступового усвідомлення суспільством природоохоронних, економічних і соціальних проблем, які впливають на стан природного середовища. Ще з початку XX ст. вперше виникли ідеї про необхідність сталого розвитку, а вперше висунув концепцію ноосфери (сфери розуму), в основі якої лежить ідея гармонізації взаємодії суспільства та природи, В. Вернадський [1]. Він вважав, що «людство, взяте в цілому, стає потужною геологічною силою, яка визначає нову геологічну еволюційну зміну біосфери», і попереджав про небезпеку, приховану у формуванні ноосфери.

Значну роль у первинному становленні концепції сталого розвитку зіграла Конференція $\mathrm{OOH}$ iз навколишнього середовища, що відбулася в Стокгольмі у 1972 році. Тут вперше було заявлено про включення до програми дій на урядовому рівні заходів щодо вирішення проблем деградації навколишнього природного середовища й прийнято програмну заяву учасників (декларація 326 принципів), план дій, який включав 109 рекомендацій. У тому числі й рекомендацію для генеральної асамблеї ООН про створення програми $\mathrm{OOH}$ із навколишнього середовища. Після цієї конференції стало можливим говорити про зародження всесвітнього природоохоронного pyxy.

Згідно з визначенням, прийнятим у 1992 році на конференції ООН з охорони навколишнього природного середовища, сталий розвиток - це такий розвиток суспільства, за якого здійснюється задоволення потреб теперішніх поколінь, але не ставиться під загрозу можливість майбутніх поколінь задовольняти свої потреби. Сталий розвиток почали розглядати як сукупність трьох компонентів - екологічної цілісності, екоефективності економічної діяльності та соціальної справедливості при доступі до благ. Таким чином, досягнення сталого розвитку досягається на основі узгодження екологічних, економічних та соціальних складових розвитку й оцінюється через груповий показник, який складається з суми індексів, що характеризують рівень соціального, екологічного та економічного процесів. Однак при цьому виникла проблема формування скалярної універсальної метрики, в якій будуть використовуватися як кількісні значення окремих факторів, так і узагальнені оцінки різного рівня.

На основі тріади економічних, соціальних та екологічних складових розробляються національні стратегії сталого розвитку або переходу до нього. У різних трактовках зазвичай робиться акцент на одному з трьох компонентів залежно від того, на що повинен бути спрямований сталий розвиток. 3 однієї точки зору, підкреслюється сталість економічної користі від використання природних благ. Інший погляд вказує на важливість збереження фізичних властивостей навколишнього природного середовища й підкреслює абсолютну цінність збереження екологічних функцій навколишнього середовища, а ступінь збереження виражається в термінах наукових знань про екологічні властивості природних цінностей.

Прихильники третього підходу акцентують увагу на важливості підтримки якості життя й цінностях, створених людиною. Це може бути важливішим за стійку економічну користь або стійке фізичне навколишне середовище. Саме в даному підході мова йде про врахування життєвих цінностей будь-якої людини та необхідність вирішення таких питань як міжрегіональна справедливість, зниження рівня бідності та ін.

Незважаючи на те, що дослідження сталого розвитку проводяться з високою інтенсивністю, існують певні труднощі й недоліки, пов'язані 3 цією концепцією.

3 огляду на те, що теорія сталого розвитку знаходиться на етапі свого становлення, багатьма вченими не визначено пріоритетність вирішення задач (економічні, екологічні або соціальні). 
Відсутня єдина дефініція сталого розвитку, що обумовлює труднощі у визначенні відповідних задач і вибору інструментів для їх вирішення. Більшість дослідників відзначають, що цій дефініції потрібно надати більш конкретне визначення 3 кількісними показниками для того, щоб ця концепція була орієнтована на прийняття практичних рішень.

Більшістю вчених сталий розвиток розглядається як сума трьох складових - екологічного, економічного та соціального розвитку. Однак таке складне явище як сталий розвиток потрібно розглядати не як суму окремих вище перехованих елементів сфер діяльності людини, а як систему, що представляє собою множину елементів, які знаходяться у взаємодії, відносинах, зв'язках і завдяки цьому представляють собою цілісність.

Для збалансованого розвитку суспільства необхідна всебічна екологізація, впровадження системи екологічного менеджменту, екологічного маркетингу, екотехнологій, що дадуть змогу забезпечити взаємодію між економічним розвитком i захистом навколишнього середовища. В розвинутих країнах досить активно відбувається екологізація національних науковотехнічних програм. В Японії, Німеччині, Нідерландах, Італії, Канаді, Франції, Великобританії та Норвегіï розроблені державні програми, спрямовані на створення екологічно важливих технологій. Наприклад, у Японії в 1990 р. створено дослідний центр інноваційних технологій для Землі, що фінансується державним і приватним сектором. Основний напрям робіт пов'язаний із глобальним потеплінням і альтернативними джерелами енергії. У Німеччині діє Програма екотехнологій Міністерства досліджень і технологій. У Нідерландах створена організація з проведення технологічних досліджень і передачі технологій, в якій екотехнології займають близько $10 \%$ діяльності. В Італії створений Фонд технологічних інновацій, де $5 \%$ коштів використовується на екотехнології. У Канаді діє Програма «Технології для екологічних рішень». У багатьох країнах екотехнології вписуються в існуючі науково-технічні програми [11, с. 89].

Практична реалізація в Україні принципів сталого, збалансованого розвитку знаходиться на початковому етапі й здійснюється у досить складних політико-суспільних, соціально-економічних та екологічних умовах. Майже весь період після Конференції ООН у Ріо-де-Жанейро наша країна була охоплена системною соціально-економічною кризою, а процес розбудови держави й становлення демократичного грома- дянського суспільства поєднувався з ринковими трансформаціями в усіх галузях і сферах економіки. У цьому полягають національні особливості, проблеми й труднощі переходу України до моделі сталого - економічно, соціально й екологічно збалансованого - розвитку.

Перспективи реалізації в Україні принципів сталого розвитку не можна розглядати окремо від здійснюваних у державі ринкових реформ. Перехід до сталого розвитку як країни у цілому, так і окремих іiі регіонів має відбуватися у тісному взаємозв'язку 3 радикальною структурною й техніко-технологічною перебудовою суспільного виробництва на основі прискорення темпів НТП, зокрема у напрямі всебічної екологізації не лише базових галузей економіки, а й усіх сфер людської діяльності. Основними інструментами втілення концепції сталого розвитку мають бути:

- регуляторна база (стратегічні документи, закони, нормативні вимоги, директиви);

- економічні інструменти (податки і збори, податкові гальма і субсидії);

- добровільні заходи (інформування про зміст, можливості та переваги сталого розвитку, консультації й підтримка основних стейкхолдерів).

Особливо важливим для прискорення переходу на модель сталої економіки в Україні є організація співпраці між основними учасниками цього процесу: уряд; науковці; громадські організації; громадяни; бізнес.

До втілення концепції сталого розвитку повинні долучитися всі сектори суспільства. І слід відзначити, що ця робота вже розпочалася. Приєднавшись до Декларації тисячоліття у вересні 2000 року, Україна взяла на себе низку зобов'язань під назвою «Цілі розвитку тисячоліття для України», що $є$ орієнтирами розвитку країни у середньостроковій перспективі (до 2015 року). На державному рівні проводиться робота 3 формування сприятливих правових умов: затверджена Концепція національної екологічної політики на період до 2020 р.; прийнята Стратегія національної екологічної політики на період до 2020 р., розроблена Концепція переходу України до збалансованого (сталого) розвитку. Науковці та громадський сектор активно долучаються до реалізації в Україні принципів сталого розвитку. Окремі українські промислові підприємства вже сьогодні починають здійснювати екологізацію своєї діяльності та реалізують заходи щодо зниження викидів шкідливих речовин у навколишнє середовище, лідируючи серед інших країн пострадянського простору. Зокрема, ВАТ «Запоріжсталь» - представник реального сектора еконо- 


\section{EKOHOMIKA}

міки - успішно впроваджує екологічні програми, що $є$ досить важливим прикладом для інших підприємств. Прогрес підприємства в сфері охорони навколишнього середовища вражає: за останні 10 років викиди пилу в атмосферу знизилися на $41 \%$, скидання стічних вод - на $30 \%$; на підприємстві підвищили повторне використання технічної води на $86 \%$ [12].

Однак реалізація принципів сталого розвитку в Україні відбувається вкрай повільно. Для активізації цього процесу необхідно здійснити низку заходів, розроблених на основі дослідження досвіду розвинутих країн світу, зокрема сприяння розвитку законодавства, яке стимулює розвиток сталої економіки, у т. ч.:

- розробка та затвердження Стратегії сталого розвитку України;

- розробка й прийняття Національній стратегії та Національного плану дій збалансованого (сталого) розвитку України;

- застосування ціноутворення, що відповідає принципам збалансованого розвитку і включає відмову від неефективних субсидій, оцінку природних ресурсів у грошовому виразі та введення податків на те, що шкодить навколишньому середовищу;

- реформування систем «екологічного» оподаткування, що передбачає зміщення акценту з податку на робочу силу на податки на забруднення, у тому числі введення податку на двоокис вуглецю;

- політика державних закупівель, яка заохочує виробництво екологічної продукції і використання методів виробництва, що відповідають принципам сталого розвитку;

- створення системи торгівлі викидами.

Стимулювання дотримання законодавства шляхом:

- підтримки постійного діалогу між органами управління та промисловістю;

- посилення культури соціальної відповідальності серед підприємств.

Підтримка інноваційних компаній через формування позивного іміджу та обміну інформаці$\epsilon ю$.

Утворення й посилення ролі існуючих кластерів поширення знань і технологій, наприклад:

- грінкубатори чи дослідницькі центри при університетах;

- посилення зв'язків між промисловістю та університетами;

- цільова державна підтримка досліджень і розробок, пов'язаних зі створенням екологічно чистих технологій.
Організація подій для обміну ноу-хау для науково-дослідних установ та компаній, що пропонують енерго- та ресурсоефективні рішення.

Сприяння доступу різних галузей до дешевих фінансових ресурсів:

- надання інформації про джерела фінансування;

- стимулювання забезпечення державних гарантій для стратегічних проектів;

- зростання державних інвестицій у розвиток інфраструктури, що відповідає принципам сталого розвитку (включаючи громадський транспорт, відновлювані джерела енергіi, будівництво енергоефективних будівель), і природний капітал для відновлення, підтримки й (де це можливо) збільшення обсягу природного капіталу;

- створення державного фонду для інновацій чи іншої форми державного фінансування проектів, направлених на розвиток сталої економіки.

Забезпечення платформи для поширення інформації, створення медіаресурсів, які б покривали інтереси різних зацікавлених сторін і висвітлювали потребу, можливості та прогрес iз сталим зростанням.

Висновки. Отже, неминучість зміни Україною моделі розвитку очевидна, адже розвиток виробництва і зростання масштабів господарської діяльності, в ході яких людина використовує дедалі більшу кількість природних ресурсів, зумовлюють тотальне посилення антропотехногенного тиску на довкілля та порушення рівноваги в навколишньому природному середовищі, що, в свою чергу, призводить до загострення соціально-економічних проблем. Одночасно 3 вичерпанням запасів невідновлюваних сировинних та енергетичних ресурсів посилюється забруднення довкілля, особливо водних ресурсів та атмосферного повітря. Соціально-економічний розвиток має грунтуватися на принципах врахування можливостей природних комплексів витримувати антропотехногенні навантаження i забезпечувати нормальне функціонування біосфери й локальних екосистем. Це можливо за умови переходу на модель сталого розвитку. Спираючись на раціональний підхід до використання ресурсів і на інноваційні технології, Україна зможе вийти з економічної кризи і підвищити конкурентоспроможність української економіки.

Інструментально в рамках концепції сталого розвитку одним із основних інструментів мають стати інновації, що дадуть можливість вивести економіку України на новий рівень розвитку. Однак характер цих інновацій має бути екологічно орієнтованим і спрямованим на зниження 
деструктивного впливу на навколишнє середовище. Все це вимагає від України створення відповідних умов, що зацікавить приватний сектор активно працювати в неприбутковій екологічній сфері. Вирішення цього завдання можливе не

\section{БІБЛІОГРАФІЯ}

1. Вернадский В. И. Живое вещество. - М. : Наука, 1978. - 358 c.

2. Галушкіна T. П. Теоретико-методологічні засади природо-ресурсного менеджменту в Україні / Т. П. Галушкіна, А. Й. Жемба // Вісник національного університету водного господарства та природокористування: зб. наук. праць. - Рівне, 2010. - Ч. 2, № 4 (44). - С. 24-34.

3. Довкілля України у 2010 році [Електронний ресурс] / Сайт Державного комітету статистики України. - Режим доступу: http://www.ukrstat.gov.ua.

4. Довкілля України у 2011 році [Електронний ресурс] / Сайт Державного комітету статистики України. - Режим доступу: http://www.ukrstat.gov.ua.

5. Ершов М. В. Экономический рост: новые проблемы и новые риски / М. В. Ершов // Вопросы экономики. - 2006. - №9. - С. 50-59.

6. Карпінський Б. А. Макроекономіка: зростання і сталий розвиток : навч. посібн. / Б. А. Карпінський, С. М. Божко, О. Б. Карпінська. - К. : Вид. дім «Професіонал», 2006. - 282 с.

7. Макарова Н. С. Економіка природокористування: навч. посібник / Н. С. Макарова, Л. Д. Гармідер, Л. В. Михальчук. - К. : Центр учбової літератури, 2007. - 322 с. тільки в рамках традиційних методів державного регулювання, але й за допомогою пропаганди інноваційної культури, що стане темою подальших досліджень.

8. Медоуз Д. Пределы роста. 30 лет спустя / Д. Медоуз, Й. Рандерс, Д. Медоуз ; пер. с англ. Е. С. Оганесян. - М. : ИКЦ «Академкнига», 2007. - 342 c.

9. Нельсон Р. Эволюционная теория экономических изменений / Р. Нельсон, С. Уинтер. - М. : Финстатинформ, 2000. - 474 с.

10. Проект водної стратегії України на період 2011-2020 років [Електронний ресурс] / http://www.scwm.gov.ua/fls/vdr.htm.

11. Яковец Ю. В. Глобализация и взаимодействие цивилизаций / Ю. В. Яковец. - М. : Экономика, 2001. - 346 с.

12. Сайт новин ТСН. [Електронний ресурс] / http://tsn.ua/groshi/v-ukrayini-pochinayut-

realizaciyu-koncepciyi-zelenoyi-ekonomiki-napromislovih-pidpriyemstvah.html

13. Forrester Jay $W$. World Dynamics. Portland, Oregon: ProductivityPress, 1970.

14. Meadows D. H. The Limits to Growth : A Report for the Club of Rome's Project On The Predicament of the Mankind / D. H. Meadows. NewYork : Universe Books, 1972. - 205 p. 